\title{
THE PECULIARITIES OF USING TED TALKS MATERIALS IN ESL CLASSROOMS
}

This article presents TED Talks materials as an educational tool of teaching English in secondary and higher educational institutions. The authors describe such advantages of TED Talks materials as their authenticity, availability, variety, utility, user-friendly usability of the website with the materials, and existence of scripts for each video. The authors prove that TED Talks materials are effective for developing students' speaking skills and extending their vocabulary by describing the experience of conducting English classes with the use of TED Talks materials during the professional pedagogical practice, the results of which are also given in this article. After 34 English lessons with the use of TED Talks materials within the framework of the elective course «English for 
Academic Purposes» for 8-11 grade pupils, the participants of the classes demonstrated better public speaking skills and could speak on different topics for more than 10 minutes without any visual aids.

Keywords: authentic materials, TED Talks materials, educational activities, listening skills, speaking skills, English class.

\section{Introduction}

The development of English language communicative competence requires using new approaches and advanced technologies nowadays (Azimova, 2019). Various authentic materials play a huge role in the development of English speaking and listening skills for students because they provide a great number of sources for teaching schoolchildren English (Losada, Insuasty, Osorio, 2017; Belmaz, 2019). Ted Talks satisfy the characteristics of audiovisual authentic materials (Gilmore, 2007); so, further, we are going to consider the peculiarities of using them while teaching English.

One of the biggest advantages of authentic materials is that they were originally created for native speakers (Bajrami, Ismaili, 2016). That is, students who study English using such authentic videos will learn how to decode the rapid speech of natives and their fluent pronunciation of words. Authentic videos provide "the real language», which is culturally relevant and contextually rich (Spelleri, 2002). Such videos can be used in the classroom as a way of presenting the content and initiating discussions; they can also be employed as an illustration for a particular topic, content or situation, as well as for self-study (Bajrami, Ismaili, 2016). Authentic videos can also motivate students to learn the English language. Christopher and Ho (1996) explain why learning English with the use of videos is much more interesting for students than other types of authentic materials: firstly, students can enjoy music and customization elements; secondly, videos provide topics and ideas for discussion (p. 190). Authentic video materials develop speaking and listening skills through the use of common themes, language functions, and grammar presented in the video (Noriko, Chi, 2004).

Such authentic materials include videos from the website www.TED.com that can engage modern students in forming their speaking skills with pleasure by assisting in «making one think», allowing students to "discuss complex topics», enabling "learning to express one's arguments» and "working independently, in one's rhythm» (Ivanova, Malygina, 2017). The availability of TED Talks lectures allows teachers to conduct various kinds of educational activities with their students. Such activities include finding specific terms, synonyms for certain words, as well as finding more accessible contextual information on the topic or subject of a conversation. Ted Talks materials are widely used by English teachers worldwide. For example, in Japan, teaching staff use TED Talks to promote the development of autonomous listening strategies, the development of listening fluency, vocabulary learning, and extensive conversational practice through discussions, thanks to a variety of topics related to global issues that can serve as a great start to a dispute (Graham, Lavigne, Fogal, 2012).

Although TED talks are a popular kind of infotainment but any teacher can use them in the teaching process, which contributes to the development of a number of competencies, such as value-sense, general cultural, information, communication, personal self-improvement competencies, etc. (Safonkina, 2005). Moreover, they have been found to be effective in not only developing listening skills but also in providing the material that inspires both teachers and students and encouraging students to engage in discussion, research, and lifelong learning (Yu-jung, Hung-Tzu, 2015).

The relevance of this article lies in the significant distribution of the materials in question as an educational tool all over the world, which requires the development of guidelines for their usage in order to reach high scores in teaching English.

The novelty of the research lies in an attempt to offer an algorithmized methodological description of the usage of TED Talks materials in educational process which can be used by teachers for conducting speaking classes at secondary and higher educational institutions.

The lexical composition of TED Talks lectures is very rich in all sorts of terms, idioms, phraseological units, as well as simple everyday phrases that can be useful when learning English. Before choosing a video, the teacher should make sure that its lexical composition corresponds to the level of language abilities of his students. The analysis of the lexical composition of TED Talks lectures will help the English teacher in the preparation of the lesson to identify the degree of difficulties students can encounter. TED Talks are useful for developing lessons of English for academic purposes (Curry, 
2020). Moreover, TED Talks lectures are popular among teachers and learners of English as a second foreign language (ESL) (Nurmukhamedov, 2017). It is quite easy to perform a lexical analysis of TED Talks videos. The website www.TED.com has a very convenient feature: under each video there are scripts in English and in several other languages. Videos, scripts, and transcription to them are placed in a convenient location, which helps to find them easily. Consequently, these aspects of the web page create a more enjoyable language learning experience for those watching TED videos (Park et al, 2013).

A very serious approach to the development of a lesson using TED Talks lectures is required. Since a competently designed system of tasks aims at the development of speech competencies, and this fact, in turn, contributes to the formation and maintenance of communicative motivation in learning a foreign language. We offer our version of the use of TED Talks materials in English lessons for upper secondary school.

\section{Aim of the article}

The article is aimed at showing ESL teachers a new approach of teaching English that can really improve the students' readiness for unprepared spontaneous speech. Some teachers have already used TED Talks materials while others have just heard about them. However, ESL school teachers in Kazakhstan do not consider TED Talks as the basic or even supplementary means for teaching English because the website's materials are not included in the official instructional and methodological letters, based on which all instructors design their lesson plans («Instructional and methodological letters»). In this regard, we want to show that using TED Talks materials are worth trying by creating a series of English classes with the application of TED Talks videos for 8-11 grade learners.

\section{Methods and results.}

The introduction of TED Talks materials into English classes as an educational tool started with the designing an elective course «English for Academic purposes» for 7-11 grades estimated at 34 academic hours and coordinated with the Karaganda City Department of Education. 14 students ( 6 - from the 7 th grade; 4 - from the $8^{\text {th }}$ grade; 2 - from the $9^{\text {th }}$ grade, and 2 - from the $10^{\text {th }}$ grade) attended one class per week within 6 months of studying at school. At the beginning, the students of 7 th and 8th grades were able to understand the gist of the video, could express their opinion by using such short phrases as "l agree with the speaker», "l liked the topic of the video» etc. In other words, most of those students could not give the full answer to a question. The students of 9th and 10th grades were more active at the lessons due to wider background knowledge. However, their answers were not full and varied either. The pupils' language skills were measured in accordance with the CEFR scale - most of them had A2 level (The CEFR Levels, 2020). Hereinafter we describe the structure of the lesson, which can be used as an example, and, in conclusion, we will show how students' language skills have changed according to CEFR (The CEFR Levels, 2020).

At the beginning of the course, we asked the school students if they have heard about TED Talks lectures, whether they are interested in learning English with the use of such materials, and what their expectations from the program are. The questionnaire results showed that $80 \%$ of the respondents have known of the video lectures TED Talks before but never used them while studying English. 90\% of the school students wanted to improve their speaking skills and vocabulary by the end of the course. We also asked the learners what topics they would prefer to consider. The answers to this question varied a lot. However, such themes as technologies, mass media, social media, and advertisement dominated; so, we chose some videos about it from www.TED.com and designed the lessons to work on the chosen topics.

We conducted 10 face-to-face English classes within the framework of the designed course «English for Academic Purposes». Each of our face-to-face lessons started with a greeting and questions that could help to set students up for work as well as language activities, such as: "How are you?», «How was your weekend?», "Did you enjoy your weekend?», "Do you like the weather today?» etc. The next step involved watching a video of the TED Talks lecture. Let's take a lecture by a chemist Ilona Stengel on «The Role of Human Emotions in Science and Research» (Stengel). In this video, llona Stengel told the audience how emotions and feelings assisted the speaker and her colleagues in making a breakthrough in the study, on which they had been working for a long time. The video material was selected in accordance with the calendar thematic planning, which allows students to consolidate the themes already covered, as well as learn something new and consider the topic from a different angle. The pupils understood what the video was about and proved this by taking an active part in the discussion of this lecture. 
It is crucial that video viewing should consist of pre-demonstration, demonstration and postdemonstration stages. At the pre-demonstration stage, students needed to guess what the video is about by its name. They also needed to answer questions related to the topic of the video such as "What is your attitude to science?», "What is your favorite science subject and why?» etc. Students could take turns to answer the questions to the teacher; they could also ask each other questions related to this topic thus performing group work and extending their speaking time. Questions are an important step, as they encourage students to enter into a discussion with a teacher or among themselves, and this, in turn, will help them not be distracted from work and will keep them focused and motivated.

The demonstration phase involved watching a TED Talks lecture with subtitles, for students to understand the speaker's quick speech better. This allowed students to write out new words and subsequently ask the teacher about their meaning. Nevertheless, if there was enough time, the teacher could first play the video without subtitles and see how many students understood the main idea. And only the second time the video may be then shown with subtitles.

After watching the video, the teacher asked the students about the main idea that the speaker was trying to express to clarify how well they comprehended the speech of the native speaker and whether they were able to get the gist from a large amount of information.

At the next stage students were divided into groups, and each group was given a different part of the script; so, all groups had different texts where words from the speech had been omitted and needed to be inserted by listening to the speech carefully again and again. Such open cloze tasks made the students learn to decode and recognize individual words in the speech of a native English speaker. It was also a task aimed at checking their attentiveness and listening for details.

After all groups completed the task, students from each group were asked to read the passage given to them already with the filled-in gaps. Then, the teacher displayed on the screen the text with right words inserted, and the students had to check the spelling of the words and correct their mistakes.

At the post-demonstration stage unfamiliar words and phrases that occurred in the speech were analyzed with the help of a presentation prepared for this purpose. The teacher might complicate the task a little and make the analysis of new words more interesting by asking students to guess the meaning of a word in the context of a sentences taken from a TED Talks lecture script. Students did not have to translate these words into their native language instead they were asked to explain their meaning in English. If none of the students gave the correct answer, the meaning of the word was displayed on the screen, and the students needed to make a sentence with it. Making sentences with these words and phrases helped students to remember them and use them in speech in the later dispute.

At the end of the class, students were engaged in the discussion. Such questions as «Do you agree with the speaker?», "Do you prefer to suppress or to show your emotions?» "Have you ever faced a similar situation as the speaker has?» enabled to do this. Students should learn to speak, so this stage was mandatory. In addition, a few minutes at the end of the lesson were allocated for reflection. During such a lesson, students developed listening and speaking skills. Moreover, they improved their team-building skills and managed to replenish their vocabulary.

Unfortunately, the global pandemic situation intervened in our plans, and we had to stop conducting our face-to-face classes. Instead, we started to have online ESL lessons, but not all participants could join our classes in Zoom platform. However, we were able to teach 4 online classes, whose structure did not differ from the face-to-face ones a lot. For example, for one of our online lesson, we chose the video "Social Media and the End of Gender» by Johanna Blakley, the Deputy Director of the Norman Lear Center. The choice of the video was justified by the contemporary youth's growing attention to various social media especially during the period of their isolation. While designing the lesson, we analyzed different types of technologies and decided to gather all lesson stages in one presentation - instructional media, created with the help of one of the most well-known multimedia creation tools PowerPoint. The lesson was aimed at developing the puplis' speaking and writing skills by watching the lecture and doing pre-, while-, and postwatching tasks. The warm-up phase involved the following issues such as "Do you often use social media?» "When did you first use social media?» "What is the best thing about social media?» "Who uses social media most in your family?» These problems helped to break the deadlock and involve learners in further work. 
To set the background of the lesson, we showed the photo of the speaker and the title «Social Media and the End of Gender» so that our learners can predict the meaning of the video. We facilitated further observation and tasks by teaching new words in advance. For this purpose, we created an interactive activity with the help of an instrument called Visme.

While-watching phase involved two activities. When watching the video for the first time, our students answered such questions as "What is the main idea of the speech?» «Do you agree with the speaker?» "What is your attitude towards this lecture?» For the second time, they needed to arrange the information from the video in the correct order with the help of another instructional interactive, created in the same tool Visme.

The post-watching phase involved data consolidation with the help of an interactive quiz, created in the tool, called Genial.ly. We also asked our learners to write a short review (at least 7 sentences) on the video and thereby practiced their writing skills. Students should learn to write, so this stage is mandatory.

In addition, a few minutes at the end of the lesson were allocated for reflection, during which the students answered if they liked the lesson, what the most useful information for them was, what part of the lesson was the most interesting.

\section{Results and discussion}

Altogether we conducted fifteen classes and interviewed our school students again. The questionnaire consisted of 7 questions and showed the following results:

1) The course helped $100 \%$ of attendees to develop their speaking skills and $20 \%$ - to overcome the fear of speaking. By our evaluation most of the students in the group who had had A2 level of speaking skills, after the completion of the course were able to speak at the level B1 confidently giving reasons and explanations. We could also observe the development of listening skills as with time pupils started to understand videos better which was obvious in the post-watching discussion.

2) $60 \%$ of students became more positive about TED Talks lectures after the course although 40\% knew the materials before.

3) $60 \%$ of students enjoyed discussion of the topics, 20\% liked the group work, and 20\% were pleased with all activities.

4) $70 \%$ of students found our course complete enough, but $30 \%$ would add such topics as History of English, English accents, and slang to the course.

However, despite interesting online classes, the majority of our participants agreed that face-to-face lessons are better anyway; so, we can declare that the role of the teacher and his/her presence in the life of his/her learners is crucial.

\section{Conclusion}

As a result, an ordinary English lesson became more interactive by involving TED Talks materials in the educational process. It was confirmed in practice that students are highly enthusiastic to take part in such a lesson. However, for achieving real improvements it is necessary to follow the three stages described in the article, actively involve pupils in discussion impelling them to use new words from the scripts, and combine group work with individual speaking. TED Talks materials are very effective in teaching English, thanks to the compelling presentation of material by the speakers, their use of authentic speech, the ability to switch on subtitles and see scripts for each video. So, they can be used as a tool to design English lessons that will be informative and entertaining thus inducing the students to proactively participate in the learning process.

\section{References}

Azimova, Sayera (2019). The Communicative Approach in English Language Teaching. Bulletin of science and practice, 5 (4), 471-475 (eng).

Bajrami, L. \& Ismaili, M. (2016). The Role of Video Materials in EFL Classrooms. Procedia - Social and Behavioral Sciences, 232, 502-506 (eng).

Christopher, E. \& Ho, S. (1999). Lights, Camera, Action: Exploring and Exploiting Films in Self-access Learning. Taking control: Autonomy in Language Learning. 185-200 (eng).

Curry, N. (2020, April 28). Supporting Every Teacher: 8 Tips for Developing Academic Speaking, Listening, Reading, and Writing in Online Contexts. Retrieved from : https://www.cambridge.org/elt/blog/2020/04/22/ developing-academic-language-skills-in-online-contexts/ (eng).

Belmaz, Yaroslava (2019). Criteria of efficiency of higher education teachers (us and Great Britain experience). Scientific Journal of Khortytsia National Academy. (Series: Pedagogy. Social Work) : scientific journal I [editorial board : V. Nechyporenko (chief editor) and others]. Zaporizhzhia : Publishing house of the 
Municipal Institution of Higher Education -Khortytsia National Educational Rehabilitation Academy of Zaporizhzhia Regional Council, Iss. 1(1). 74-82 (eng).

Gilmore, A. (2007). Authentic Materials and Authenticity in Foreign Language Learning. Language Teaching 40 (2), 97-118 (eng).

Graham, F., Lavigne, A. \& Fogal., G. (2012) Promoting Learner Autonomy through Current Global Issues.

Presentation delivered at the 46th Annual TESOL Convention. Philadelphia, PA (eng).

Ivanova, A. \& Malygina, E. (2017) Possibilities of Using Modern Media Content TED Talks in Teaching English as

a Second Foreign Language. Bulletin of Chelyabinsk State Pedagogical University, No. 3, 49-56 (eng).

Noriko, I. \& Chi, Julie C. (2004). Authentic Video in the Beginning ESOL Classroom: Using a Full-Length Feature

Films for Listening and Speaking Strategy Practice. English Teaching Forum 2004, 30-32 (eng).

Nurmukhamedov, U. (2017). Lexical Coverage of TED Talks: Implications for Vocabulary Instruction. TESOL Journal, 8(4), 768-790 (eng).

Park, Sun-Mih, \& Cha, Kyung-Whan (2013) Pre-service Teachers' Perspectives on a Blended Listening Course Using TED Talks. Multimedia-Assisted Language Learning, 16(2), 93-116 (eng).

Losada, C. A. C., Insuasty, E. A., \& Osorio, M. F. J. (2017). The Impact of Authentic Materials and Tasks on

Students' Communicative Competence at a Colombian Language School. Retrieved from: https://www.redalyc.org/jatsRepo/1692/169248921007/html/index.html (eng).

Safonkina, O. (2005) The Use of Modern Computer Technologies in Teaching Foreign Languages. Materials of the Regional Conference, 200-201 (eng).

Spelleri, M. (2002). From Lessons to Life: Authentic Materials Bridge the Gap. ESL Magazine 5 (2), 16-18 (eng).

The CEFR Levels. (n.d.). Retrieved from : https://www.coe.int/en/web/common-european-framework-referencelanguages/level-descriptions (eng).

Yu-jung, C. \& Hung-Tzu H. (2015) Exploring TED Talks as a Pedagogical Resource for Oral Presentations: A Corpus-Based Move Analysis. English Teaching \& Learning 39.4 (Special Issue 2015), 29-62 (eng).

\section{ОСОБЕННОСТИ ИСПОЛЬЗОВАНИЯ МАТЕРИАЛОВ ТЕD ТАLКS НА УРОКАХ АНГЛИЙСКОГО ЯЗЫКА}

Анна Калижанова, научный сотрудник Академии Болашак, Караганда, Казахстан, е-таil: anna.kalizhanova2017@gmail.com

Татьяна Писарева, студентка Академии Болашак, Караганда, Казахстан, e-таil: pisareva687@gmail.com

B статье рассматриваются материалы TED Talks как инструмент обучения английскому языку. Представлены преимущества аутентичных материалов TED Talks как образовательного инструмента: аутентичность, разнообразие, функциональность, удобство использования сайта с материалами и наличие скриптов к каждому видеоматериалу. Особое внимание уделено способам развития навыков говорения и слушания с помощью данных материалов. Представлены примеры разработки как очного, так и онлайн урока с использованием материалов TED Talks, которые были проведены в ходе профессиональной педагогической практики, результаты которой также описаны в статье. После 34 уроков английского языка с использованием материалов TED Talks в рамках элективного курса «Английский для академических целей» для 8-11 классов, учащиеся, которые посещали уроки, смогли значительно улучшить свои навыки говорения по сравнению с первоначальными, а именно увеличить продолжительность речи без визуальной опоры до 10 минут.

Ключевые слова: аутентичные материалы, материалы TED Talks, обучающие задания, навыки аудирования, навыки говорения, урок английского языка.

\section{ОСОБЛИВОСТІ ВИКОРИСТАННЯ МАТЕРIAЛІВ TED TALKS НА УРОКАХ АНГЛІЙСЬКОÏ МОВИ}

Ганна Каліжанова, науковий співробітник Академії Болашак, м. Караганда, Казахстан, е-таil: anna.kalizhanova2017@gmail.com

Тетяна Пісарева, студентка Академії Болашак, м. Караганда, Казахстан, е-таil: pisareva687@gmail.com 
У науково-методичній статmі здійснений аналіз матеріалів TED Talks як навчального інструменту викладання англійської мови в закладах середньої та вищої освіти. Виявлені такі переваги матеріалів TED Talks, як їх справжність, доступність, різноманітність, корисність, зручність користування вебсайтом з матеріалами та наявність сценаріїв для кожного відео.

Представлена методика проведення уроків з використанням матеріалів TED Talks, яка включає чотири обов'язкові складові. По-перше, кожен урок має розпочатися з привітання та запитань, які могли б допомогти учням налаштуватись на роботу. Це такі запитання, як: «Як пройшли вихідні?», "Чи подобається вам сьогодні погода?» тощо. По-друге, перед переглядом відеолекції учні мають відгадати ії зміст за назвою (вигадати, про що може йтися у відео), а також відповісти на запитання, пов'язані з темою відео. Особливістю цього етапу є те, що відеоматеріал підбирається відповідно до календарно-тематичного планування, що дозволяє учням закріпити вже вивчені теми, а також розглянути відому їм тему з іншого кута. По-третє, перегляд відеолекції TED Talks, який відбувається у два етапи: перегляд лекції TED Talks із субтитрами та вдруге - без субтитрів. По-четверте, робота із мовним матеріалом. Наприклад, учнів можна розділити на групи, і кожній з них видати частину сценарію із прогалинами, запропонувавши згадати зміст лекції та заповнити прогалини. Також на етапі після демонстрації відеолекції мають бути проаналізовані незнайомі слова та фррази.

В ході дослідної роботи мовні навички учнів вимірювались відповідно до шкали CEFR.

Доведено, що матеріали TED Talks $є$ ефективними для розвитку мовленнєвих навичок учнів та розширення їх словникового запасу. Адже після 34 уроків англійської мови з використанням матеріалів TED Talks в рамках фракультативного курсу «Англійська мова для навчальних цілей» для учнів 8-11 класів учасники занять продемонстрували кращі навички публічного виступу та могли говорити на різні теми більше ніж 10 хвилин без наочних посібників.

Ключові слова: автентичні матеріали, матеріали TED Talks, навчальні завдання, навички аудіювання, навички говоріння, урок англійської мови.

Authors' contribution: Kalizhanova A. $-50 \%$; Pisareva T. $-50 \%$

Cтаття надійшла до редакції / Received 26.03.2020

Прийнята до друку / Accepted 26.05.2020

Унікальність тексту 97,8 \% (Unicheck ID 1005370167)

(C) Kalizhanova Anna, Pisareva Tatyana

УДК 378.011.3-051:373.3091.212-026.15-027.1(043.5)

Людмила Михайлівна Корольова ORCID ID: 0000-0003-4963-9465 кандидат педагогічних наук, старший викладач кафедри педагогіки та методик навчання, Хортицька національна академія, м. Запоріжжя, Україна luseyna.77@ukr.net

\section{СУЧАСНІ ФОРМИ, МЕТОДИ Й ЗАСОБИ ПІДГОТОВКИ МАЙБУТНЬОГО ВЧИТЕЛЯ НОВОЇ УКРАЇНСЬКОї ШКОЛИ ДО РОЗВИТКУ КРЕАТИВНИХ ЗДІБНОСТЕЙ МОЛОДШИХ ШКОЛЯРІВ}

У науково-методичній статті представлені напрацювання щодо вирішення проблеми підготовки майбутніх учителів до розвитку креативних здібностей учнів початкової школи. Визначено суперечності, що гальмують процес підготовки майбутніх учителів молодшої шкільної ланки Здійснено огляд засобів підготовки майбутніх учителів до розвитку креативних здібностей учнів молодших класів у ракурсі їхнього мотиваційного значення для підвищення якості вищої освіти. Викладене авторське бачення значущості потенціалу креативної орієнтованості навчання майбутніх учителів початкових класів. Представлено досвід запровадження школи педагогічної майстерності «Кав'ярня креативності» в освітній процес закладу вищої освіти. 